\title{
Attitudes toward and the Current Adoption and Future Expectations of Working from Home in Hong Kong during the COVID-19 Pandemic
}

\author{
Xin Ping Loh ${ }^{1}$, Yongsung Lee ${ }^{1}$ (D) \\ ${ }^{1}$ Department of Geography, University of Hong Kong \\ Keywords: covid-19, working from home, attitudes, latent-class cluster analysis, Hong Kong \\ https://doi.org/10.32866/001c.28337
}

Findings

This study employs a dataset from the Hong Kong Mobility Survey to investigate attitudes towards working from home (WFH) among 901 workers in Hong Kong. A latent-class cluster analysis identified three clusters, each of which displays distinctive attitudes towards WFH. Those with positive attitudes tend to have a higher frequency of WFH while those with negative attitudes tend to have a lower frequency. Near-future expectations, however, do not appear to be affected by differences in attitudes toward WFH.

\section{Questions}

Recent studies have reported that attitudes toward working from home (WFH) have affected the adoption and frequency of WFH during the pandemic (Beck, Hensher, and Wei 2020; Conway et al. 2020; Nguyen 2021); few, however, have focused on WFH in highly dense Asian cities. In response, we answer the following questions in the context of Hong Kong.

1. What are the attitudes towards WFH among workers?

2. What are the profiles of various groups of workers?

3. How often do members of each group expect to work from home in the near future (April 2021)?

\section{Methods}

This study uses a dataset from the first wave of the Hong Kong Mobility Survey (Lee and De Vos 2022). Data collection was carried out during the fourth wave of the COVID-19 pandemic in Hong Kong from December 2020 to January 2021. Using convenience sampling, the survey targeted adults aged 18 and above living in Hong Kong. The survey was distributed through Facebook advertisements and deployed by Qualtrics. Out of 4,213 responses in total, we find 1,139 effective cases, and for this paper, we employ its worker subsample $(\mathrm{N}=901)$.

We begin by conducting an exploratory factor analysis (EFA) to derive underlying attitudinal constructs from 15 attitudinal questions that asked about WFH in a five-point Likert scale ranging from strongly disagree to strongly agree. Table 1 presents the EFA results of the attitudes towards WFH. The identified attitudinal factors are (1) distraction-while-WFH, (2) autonomy-via-WFH, (3) virtual-meeting-is-effective, (4) firm-is-supportive, and (5) technology-is-challenging. Second, we employ a latent-class cluster 
Table 1. Exploratory factor analysis on attitudinal statements towards WFH (N=901).

\begin{tabular}{|c|c|c|c|c|c|}
\hline \multirow[b]{2}{*}{ Attitudinal Statement } & \multicolumn{5}{|c|}{ Attitudinal Factors } \\
\hline & $\begin{array}{l}\text { Distraction- } \\
\text { while-WFH }\end{array}$ & $\begin{array}{l}\text { Autonomy- } \\
\text { via-WFH }\end{array}$ & $\begin{array}{l}\text { Virtual- } \\
\text { meeting- } \\
\text { is- } \\
\text { effective }\end{array}$ & $\begin{array}{l}\text { Firm-is- } \\
\text { supportive }\end{array}$ & $\begin{array}{l}\text { Technology- } \\
\text { is- } \\
\text { challenging }\end{array}$ \\
\hline $\begin{array}{l}\text { At home, I am easily distracted by } \\
\text { household chores during work. }\end{array}$ & 0.765 & & & & \\
\hline $\begin{array}{l}\text { Working from home makes me less } \\
\text { disciplined/self-controlled. }\end{array}$ & 0.630 & & & & \\
\hline $\begin{array}{l}\text { At home, I am easily disturbed by family } \\
\text { members, children, or others who live } \\
\text { together during work. }\end{array}$ & 0.504 & & & & \\
\hline $\begin{array}{l}\text { Working from home helps me avoid } \\
\text { unwanted distractions/interruptions often } \\
\text { taking place in the workplace. }\end{array}$ & & 0.604 & & & \\
\hline $\begin{array}{l}\text { I like the flexibility to decide when and } \\
\text { where to do my work. }\end{array}$ & & 0.562 & & & \\
\hline $\begin{array}{l}\text { I find my productivity in online meetings to } \\
\text { be similar to or even better than that in in- } \\
\text { person meetings. }\end{array}$ & & & 1.004 & & \\
\hline $\begin{array}{l}\text { I experience good support from my } \\
\text { employer to work from home. }\end{array}$ & & & & 0.999 & \\
\hline $\begin{array}{l}\text { While working from home, technologies do } \\
\text { not always work properly (e.g., spotty } \\
\text { internet during online meetings). }\end{array}$ & & & & & 0.517 \\
\hline $\begin{array}{l}\text { Learning how to use new technologies is } \\
\text { often frustrating (e.g., software updates of } \\
\text { online meeting/collaboration tools). }\end{array}$ & & & & & 0.499 \\
\hline $\begin{array}{l}\text { The quality of interactions during online } \\
\text { meetings is disappointing. }\end{array}$ & & & -0.325 & & 0.275 \\
\hline $\begin{array}{l}\text { I experience substantial gains in efficiency } \\
\text { when working from home. }\end{array}$ & -0.390 & 0.453 & & & \\
\hline $\begin{array}{l}\text { Working from home helps me save on large } \\
\text { expenses (e.g., commuting and parking). }\end{array}$ & & 0.450 & & & \\
\hline $\begin{array}{l}\text { At home, I have office hardware for } \\
\text { working from home (e.g., desktop/laptop, } \\
\text { camera, headset, printer). }\end{array}$ & & & & & -0.270 \\
\hline $\begin{array}{l}\text { While working from home, it is difficult to } \\
\text { draw the boundary between my work and } \\
\text { my personal life. }\end{array}$ & 0.419 & & & & \\
\hline $\begin{array}{l}\text { The nature of my job requires me to } \\
\text { physically go to work, even during the } \\
\text { pandemic. }\end{array}$ & & & & -0.289 & \\
\hline
\end{tabular}

Notes: We choose principal axis factoring with the oblimin rotation, and we compute factor scores with the pattern matrix of a rotated solution via the Bartlett score method. Loadings smaller than .25 are suppressed for brevity. We employ $R$ package $p$ syche.

analysis (LCCA) to probabilistically assign respondents into distinctive groups according to their attitudes as indicators. Next, to understand the profiles of individuals across clusters, we include inactive covariates, such as sociodemographic, household, and teleworking characteristics. 


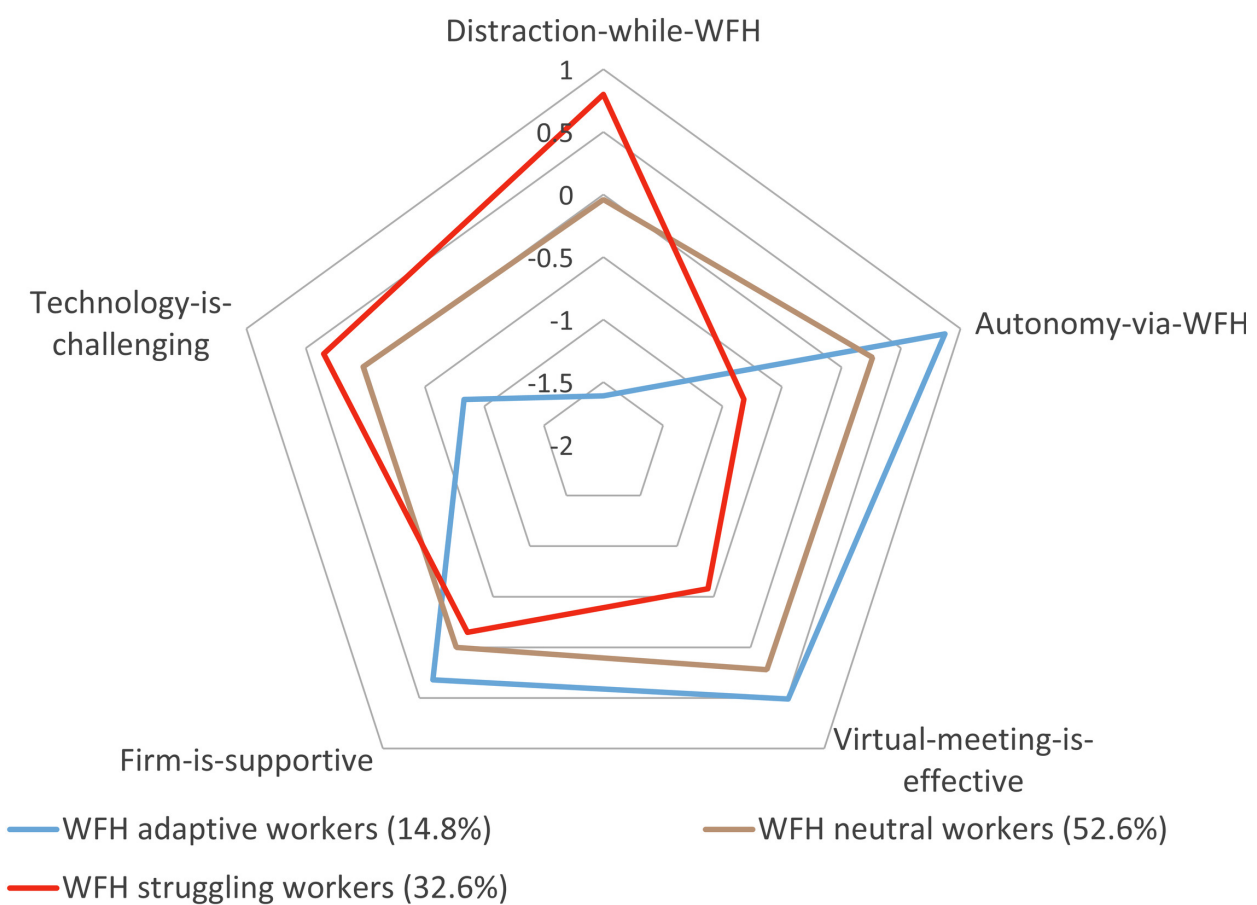

Figure 1. Average scores of the attitudinal factors for the three classes.

\section{Findings}

Figure 1 graphically illustrates the average scores of the attitudinal factors for individual clusters, or classes, and Figure 2 presents the frequency of WFH of the three classes at different time periods. In addition, Table 2 presents the class-specific probability-weighted summary statistics of the indicators and covariates.

Among the classes, WFH adaptive workers (14.8\%) express the most positive attitudes towards WFH. The majority of these workers (84.7\%) hold either a bachelor's degree or a graduate degree, which is higher than that of the remaining sample (70.2\%). Also, the portion of these workers with a monthly household income of $\$ 60,000$ or more is noticeably higher than the sample average (33.6\% vs. $27.0 \%$, respectively). Some $55.8 \%$ of this class live in the New Territories, where most new suburban towns with moderate density are located. This class has the smallest household size (3.13) with the smallest share of those with children (17.6\%), and its members have the largest residential space per capita (211 sq. $\mathrm{ft}$ ). These workers also have the highest percentage of individuals working on Hong Kong Island (40.6\%) and report the highest car ownership among the classes (15.0\%). Their average one-way commute (44.91 minutes), however, is only slightly longer than the sample average (43.94 minutes), partly because of their longer commutes and traffic congestion. Members of this class report the highest frequency of WFH before and during the pandemic (e.g., about $38.4 \%$ WFH before the third wave and $70.4 \%$ during 


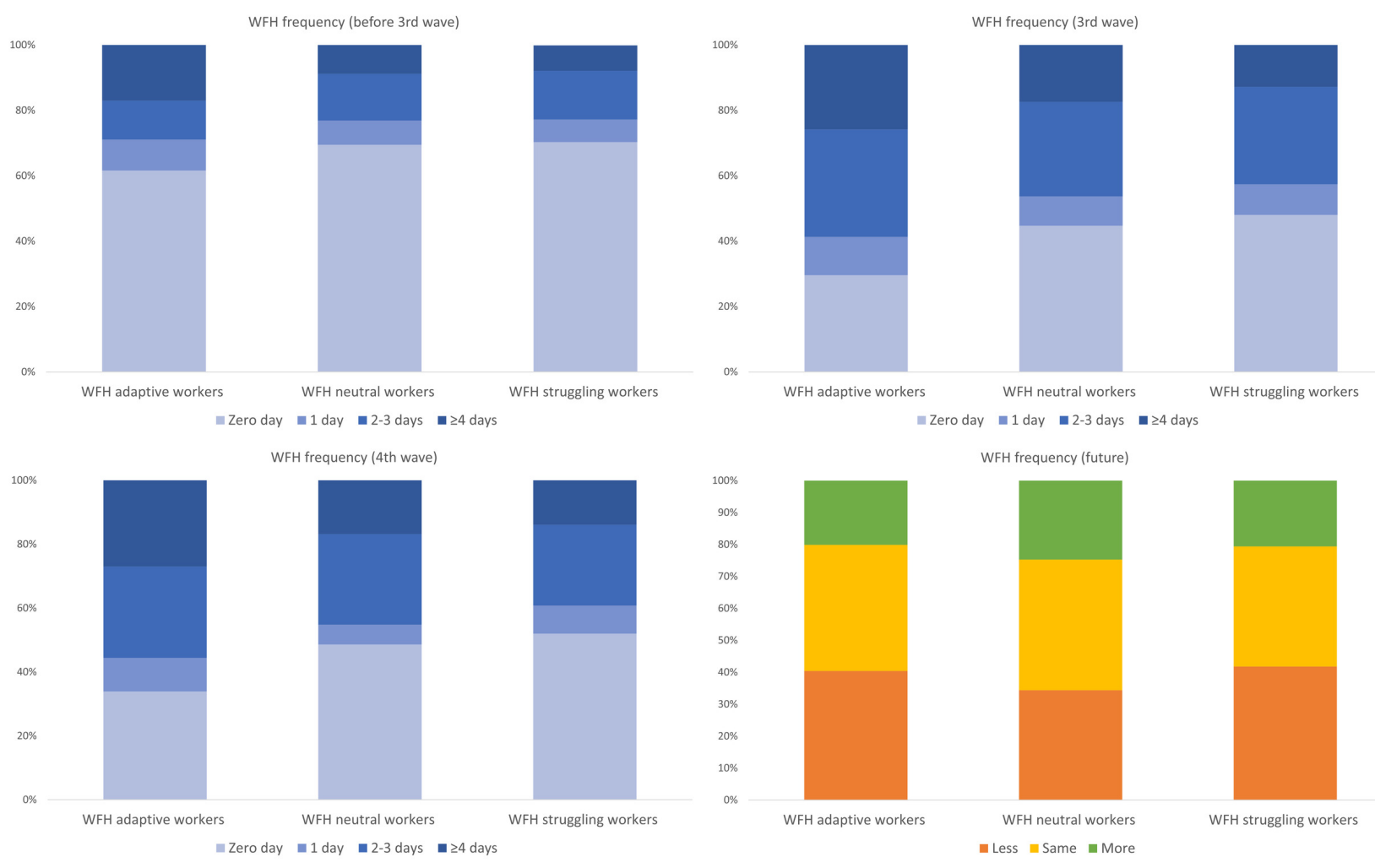

Figure 2. Frequency of WFH of the three classes at different time periods.

the third wave). Its share of teleworkers, however, slightly decreased to $66.5 \%$ during the fourth wave, possibly because people experienced 'quarantine fatigue' after working from home for several months.

WFH neutral workers (52.6\%), which account for more than half the sample, exhibit somewhat neutral attitudes towards WFH. Compared to the sample, this class consists of slightly larger shares of those aged 18-24 and $25-34$ ( $12.4 \%$ vs. $11.9 \%$ and $38.2 \%$ vs. $37.0 \%$, respectively). These workers, which comprise the largest share of those with a monthly household income of $\$ 20,000$ or below (16.1\%), live in average sized households of 3.43 and an average living space of $165 \mathrm{sq}$. $\mathrm{ft}$. per person, both of which are similar to the sample averages. The percentages of those WFH at least once a week during the third and fourth waves were $55.4 \%$ and $51.4 \%$, respectively, similar to the sample average.

WFH struggling workers $(32.6 \%)$ can be viewed as opposite to WFH adaptive workers. Adults aged 45-64 are more common in this class than in the sample ( $22.9 \%$ vs. $18.9 \%$, respectively), and its members are less-educated than those of the other classes. This class also has the highest share of members residing on Hong Kong Island (20.4\%) and in Kowloon (32.5\%), denser and less affordable than the New Territories. Workers in this class also have the largest share of those with children and live in the largest households with an 
Table 2. Distributions of indicators and covariates within clusters ( $\mathrm{N}=901)$.

\begin{tabular}{|c|c|c|c|c|}
\hline & $\begin{array}{c}\text { WFH } \\
\text { adaptive } \\
\text { workers } \\
(14.8 \%)\end{array}$ & $\begin{array}{l}\text { WFH neutral } \\
\text { workers } \\
(52.6 \%)\end{array}$ & $\begin{array}{c}\text { WFH } \\
\text { struggling } \\
\text { workers } \\
(32.6 \%)\end{array}$ & $\begin{array}{c}\text { Sample } \\
(N=901)\end{array}$ \\
\hline \multicolumn{5}{|l|}{ Indicators } \\
\hline Distraction-while-WFH & -1.61 & 0.04 & 0.80 & 0.00 \\
\hline Autonomy-via-WFH & 0.87 & 0.26 & -0.82 & 0.00 \\
\hline Virtual-meeting-is-effective & 0.51 & 0.22 & -0.58 & 0.00 \\
\hline Firm-is-supportive & 0.32 & 0.00 & -0.15 & 0.00 \\
\hline Technology-is-challenging & -0.83 & -0.02 & 0.35 & 0.00 \\
\hline \multicolumn{5}{|l|}{ Covariates } \\
\hline \multicolumn{5}{|l|}{ Age } \\
\hline $18-24$ & $11.6 \%$ & $12.4 \%$ & $11.3 \%$ & $11.9 \%$ \\
\hline $25-34$ & $36.0 \%$ & $38.2 \%$ & $35.2 \%$ & $37.0 \%$ \\
\hline $35-44$ & $35.1 \%$ & $31.6 \%$ & $30.1 \%$ & $31.7 \%$ \\
\hline $45-54$ & $11.6 \%$ & $13.0 \%$ & $16.9 \%$ & $14.0 \%$ \\
\hline $55-64$ & $5.2 \%$ & $4.1 \%$ & $6.0 \%$ & $4.9 \%$ \\
\hline 65 and over & $0.6 \%$ & $0.7 \%$ & $0.4 \%$ & $0.6 \%$ \\
\hline \multicolumn{5}{|l|}{ Gender } \\
\hline Male & $31.0 \%$ & $32.0 \%$ & $38.1 \%$ & $33.8 \%$ \\
\hline Female & $69.0 \%$ & $68.0 \%$ & $61.9 \%$ & $66.2 \%$ \\
\hline \multicolumn{5}{|l|}{ Education attainment } \\
\hline Below bachelor's degree & $15.1 \%$ & $32.0 \%$ & $33.0 \%$ & $29.8 \%$ \\
\hline Bachelor's degree & $54.5 \%$ & $46.5 \%$ & $47.0 \%$ & $47.9 \%$ \\
\hline Graduate degree & $30.4 \%$ & $21.5 \%$ & $20.0 \%$ & $22.3 \%$ \\
\hline \multicolumn{5}{|l|}{ Type of employment } \\
\hline Education and government & $19.7 \%$ & $18.1 \%$ & $15.6 \%$ & $17.5 \%$ \\
\hline Essential & $15.0 \%$ & $16.6 \%$ & $17.7 \%$ & $16.7 \%$ \\
\hline White collar & $58.3 \%$ & $61.2 \%$ & $63.0 \%$ & $61.4 \%$ \\
\hline Others & $7.1 \%$ & $4.1 \%$ & $3.7 \%$ & $4.4 \%$ \\
\hline \multicolumn{5}{|l|}{ Monthly household income } \\
\hline Below $\$ 20,000$ & $12.8 \%$ & $16.1 \%$ & $13.4 \%$ & $14.7 \%$ \\
\hline$\$ 20,000$ to $\$ 39,999$ & $27.8 \%$ & $34.4 \%$ & $36.9 \%$ & $34.2 \%$ \\
\hline$\$ 40,000$ to $\$ 59,999$ & $25.9 \%$ & $23.0 \%$ & $25.1 \%$ & $24.1 \%$ \\
\hline$\$ 60,000$ or more & $33.6 \%$ & $26.5 \%$ & $24.7 \%$ & $27.0 \%$ \\
\hline \multicolumn{5}{|l|}{ Residential district } \\
\hline Hong Kong Island & $19.1 \%$ & $17.3 \%$ & $20.4 \%$ & $18.5 \%$ \\
\hline Kowloon & $25.0 \%$ & $31.0 \%$ & $32.5 \%$ & $30.6 \%$ \\
\hline New Territories & $55.8 \%$ & $51.7 \%$ & $47.2 \%$ & $50.8 \%$ \\
\hline \multicolumn{5}{|l|}{ Household size } \\
\hline & 3.13 & 3.43 & 3.55 & 3.42 \\
\hline \multicolumn{5}{|c|}{ Average living space per person (sq. ft) } \\
\hline & 211 & 165 & 158 & 169 \\
\hline \multicolumn{5}{|l|}{ Presence of school-aged child(ren) } \\
\hline No & $82.4 \%$ & $77.1 \%$ & $71 \%$ & $75.9 \%$ \\
\hline Yes & $17.6 \%$ & $22.9 \%$ & $29.1 \%$ & $24.1 \%$ \\
\hline
\end{tabular}




\begin{tabular}{|c|c|c|c|c|}
\hline WFH frequency (befor & & & & \\
\hline Zero day & $61.6 \%$ & $69.5 \%$ & $70.3 \%$ & $68.6 \%$ \\
\hline 1 day & $9.5 \%$ & $7.4 \%$ & $6.9 \%$ & $7.5 \%$ \\
\hline 2-3 days & $11.9 \%$ & $14.3 \%$ & $14.9 \%$ & $14.2 \%$ \\
\hline$\geq 4$ days & $17.1 \%$ & $8.8 \%$ & $7.8 \%$ & $9.7 \%$ \\
\hline \multicolumn{5}{|c|}{ WFH frequency ( $3^{\text {rd }}$ wave) } \\
\hline Zero day & $29.6 \%$ & $44.7 \%$ & $48.0 \%$ & $43.5 \%$ \\
\hline 1 day & $11.7 \%$ & $9.0 \%$ & $9.4 \%$ & $9.5 \%$ \\
\hline $2-3$ days & $32.9 \%$ & $28.9 \%$ & $29.8 \%$ & $29.8 \%$ \\
\hline$\geq 4$ days & $25.8 \%$ & $17.5 \%$ & $12.9 \%$ & $17.2 \%$ \\
\hline \multicolumn{5}{|c|}{ WFH frequency ( $4^{\text {th }}$ wave) } \\
\hline Zero day & $33.9 \%$ & $48.6 \%$ & $52.0 \%$ & $47.5 \%$ \\
\hline 1 day & $10.5 \%$ & $6.2 \%$ & $8.8 \%$ & $7.7 \%$ \\
\hline 2-3 days & $28.6 \%$ & $28.4 \%$ & $25.3 \%$ & $27.4 \%$ \\
\hline$\geq 4$ days & $27.4 \%$ & $16.8 \%$ & $13.9 \%$ & $17.4 \%$ \\
\hline \multicolumn{5}{|c|}{ WFH frequency (in April 2021) } \\
\hline Less & $40.4 \%$ & $34.4 \%$ & $41.8 \%$ & $37.7 \%$ \\
\hline Same & $39.5 \%$ & $40.9 \%$ & $37.6 \%$ & $39.6 \%$ \\
\hline More & $20.1 \%$ & $24.7 \%$ & $20.6 \%$ & $22.7 \%$ \\
\hline \multicolumn{5}{|l|}{ Work location } \\
\hline Hong Kong Island & $40.6 \%$ & $32.7 \%$ & $31.1 \%$ & $33.3 \%$ \\
\hline Kowloon & $30.0 \%$ & $34.7 \%$ & $36.9 \%$ & $34.8 \%$ \\
\hline New Territories & $29.4 \%$ & $32.6 \%$ & $32.0 \%$ & $31.9 \%$ \\
\hline \multicolumn{5}{|c|}{ Average one-way commute (minutes) } \\
\hline & 44.91 & 44.49 & 42.68 & 43.94 \\
\hline \multicolumn{5}{|l|}{ Car ownership } \\
\hline No & $85.0 \%$ & $87.3 \%$ & $88.9 \%$ & $87.5 \%$ \\
\hline Yes & $15.0 \%$ & $12.7 \%$ & $11.2 \%$ & $12.5 \%$ \\
\hline
\end{tabular}

Notes: Bold values indicate the highest value for each row.

average size of 3.55. They have the smallest average living space per person (158 sq. ft), which suggests insufficient space for home offices. Compared to the sample average (34.8\%), a larger percentage of members work in Kowloon (36.9\%), which shortens their commutes (42.68 minutes). Not surprisingly, members of this class are the least likely to work from home. Despite a drop in the share of zero days WFH during the third wave, their frequency of WFH at least once per week was still the lowest among the classes during both the third and fourth waves $(52.0 \%$ and $48.0 \%$, respectively).

Our results reveal that positive attitudes and perceptions of WFH do not necessarily translate into more WFH in the near future. The majority of workers in all three classes intend to either reduce or maintain the frequency of WFH in the near future. One possible explanation is that the constrained living space in Hong Kong may not support long-term WFH. According to Task Force on Land Supply (2018), the average living space per person in Hong Kong was only around 160 sq. ft. in 2018. Another possible explanation 
is that Hong Kong is a highly compact city, so most workers have a short commute between work and home. That is, the comparatively small savings in the commute time may not motivate workers to continue WFH in the future.

\section{ACKNOWLEDGEMENTS}

This study was made possible by funding from the University of Hong Kong via the Seed Fund for Basic Research for New Staff(No. 202009185039). The authors would like to thank a number of colleagues for their invaluable input and support at various stages of this project, including Patricia Mokhtarian, Giovanni Circella, Bumjoon Kang, Peter Koh, Becky Loo, Calvin Tribby, Kailai Wang, and Jinhyun Hong.

Submitted: September 01, 2021 AEDT, Accepted: September 22, 2021 AEDT

This is an open-access article distributed under the terms of the Creative Commons Attribution 4.0 


\section{REFERENCES}

Beck, Matthew J., David A. Hensher, and Edward Wei. 2020. "Slowly Coming out of COVID-19 Restrictions in Australia: Implications for Working from Home and Commuting Trips by Car and Public Transport." Journal of Transport Geography 88 (October): 102846. https://doi.org/10.1016/ j.jtrangeo.2020.102846.

Conway, Matthew Wigginton, Deborah Salon, Denise Capasso da Silva, and Laura Mirtich. 2020. "How Will the Covid-19 Pandemic Affect the Future of Urban Life? Early Evidence from HighlyEducated Respondents in the United States.” Urban Science 4 (4): 50. https://doi.org/10.3390/ urbansci4040050.

Lee, Yongsung, and Jonas De Vos. 2022. "Who Will Continue to Work from Home in Hong Kong after the COVID-19 Pandemic?” TRBAM-22-01397. Transportation Research Board 101st Annual Meeting.

Nguyen, Minh Hieu. 2021. "Factors Influencing Home-Based Telework in Hanoi (Vietnam) during and after the COVID-19 Era." Transportation, 1-32. https://doi.org/10.1007/ s11116-021-10169-5.

Task Force on Land Supply. 2018. "Land for Hong Kong: Our Home, Our Say!” 2018. https://www.legco.gov.hk/yr17-18/english/panels/dev/papers/dev20180529-booklet201804-e.pdf. 